\title{
Chapter 20 \\ Is a Participant Objectivation of Elites and Symbolic Power Possible?
}

\author{
Sylvain Laurens
}

The ethnographic account is a supremely ex post facto product of the actual uncertainty of life. (...) The subjects stand too square in their self-referenced world. The method is also patronising and condescending - is it possible to imagine the ethnographic account upwards in a class society? (Paul Willis, Learning to labour)

As suggested by this epigraph from Paul Willis, can participant objectivation, through ethnography of the dominant classes, be a tool for social scientists? This question not only implies examining the feasibility of the investigation inherent to particular types of fieldwork, but also means questioning what produces an asymmetric social position and how our professional habits structure our research practices on this type of object.

The sociology of elites has been historically structured around key issues and preferred methods. Its major issues are known: the circulation and renewal of elites ${ }^{1}$, their more or less welded character (Mills 1956), the creation of an aristocratic taste (de Saint Martin 1993) and a bourgeois ethos (Sombart and Esptein 1913; Davidoff and Hall 1987), the strength of family socialisation, the role played in social reproduction by a selective school system, the importance of minimal differentiation and distinctive practices, etc. (Veblen 1934). ${ }^{2}$

\footnotetext{
${ }^{1}$ A classic theme of Italian sociology. See in particular Vilfredo Pareto, The rise and fall of elites, 1901.

${ }^{2}$ For a review of those approaches, see Jean-Pascal Dalloz, Sociology of elite distinction. From Theoretical to Comparative Perspectives, 2009.
}

\footnotetext{
S. Laurens $(\bowtie)$

Centre Maurice Halbwachs, Ecole des hautes études en sciences sociales, Paris, France e-mail: laurens@ehess.fr
} 
To address these various issues, the sociology of elites often mobilises very classical methods: mainly statistical analysis, secondary analysis or textual interviews, but rarely historical analysis (Elias 1983) or ethnography. ${ }^{3}$ This predominance of statistical approaches is probably due to the objectifying ability of these techniques and the impression of direct accessibility to data given by biographical directories. Research design also seems less risky through this set of methods because many classical sociologists have previously utilised it: Bourdieu, ethnographer of Algerian workers, abandoned his notebooks in favour of statistics in The State Nobility; C. Wright Mills of the The Power Elite also favoured prosopography and data obtained through media over other methods. We will not here re-examine the opposition between quantitative and qualitative methods; suffice it to say that the use of quantitative methods (especially dominant today are Optimal Character Recognition (OCR) and web scraping, which make the creation of large corpuses possible), should not prevent a crossing of methods in order to avoid the confinement of the sociology of elites within a 'sociology at a distance' where respondents are simply found in Who's Who and other biographical directories.

Combining statistics with ethnography and qualitative methods is especially important when one tries to mobilise a sociology of dispositions, through the notion of habitus and through exploring the black box of 'symbolic capital'. Without ethnography, how do we account for the ability given to dominant agents to exert, within a field, a form of power related to the merger of possessed (economic and cultural) capital? How do we analyse this located authority and the specific form of capital that social agents produce and reproduce in their daily activities?

Advocating for an ethnography of symbolic power immediately, however, raises other issues. How do we write an ethnography on the exercise of power? Can we reduce power to its symbolic dimension? How do we integrate the fact that fieldwork on dominant classes gives the sociologist a particular position within a game of asymmetric relations? As underscored by the anthropologist Alban Bensa, 'under the risk of naturalizing the structures, the ethnographer has an interest, wherever possible, to integrate into his experience the historical conditions of the fulfilment of this experience' (Bensa 2006a, b, p. 49). ${ }^{4}$ We will push this argument further by asking whether it is possible to objectify symbolic capital from this asymmetric, and often unfavourable, social position given to the social scientist in the field.

\footnotetext{
${ }^{3}$ With few exceptions of course: Michel Pinçon and Monique Pinçon-Charlot, Grand fortunes: dynasties of wealth in France, New York, Algora, 1999. Cris Shore and Stephen Nugent, Elite cultures: anthropological perspectives, London/New York, Routledge, 2002.

${ }^{4}$ For a translation of these works: Alban Bensa, "Pierre Bourdieu and Anthropology", in R. Lardinois \& M. Thapan (éds.), Reading Pierre Bourdieu in a dual Context: essays from India and France. London/New-Delhi, Routledge, 2006.
} 


\section{The Ethnography of Symbolic Power: A Blind Spot in the Division of Labour Among Sociologists of Elites}

Ethnologists of the bourgeoisie have very minutely dissected the elements of 'bourgeois culture' ${ }^{5}$ They have used ethnography for a very specific purpose, attempting to isolate the values of this social group without seeking to link their description to a general hypothesis on what symbolic power is. The 'cult of legacies', the strong socialisation into the 'legitimate culture', the family's stronghold, the exercise of power over space, and the time spent on the maintenance of social capital through institutions such as selective clubs are all classical topics for specialists of the aristocracy and the bourgeoisie.

\section{The Traditional Arenas of the Ethnography of 'Bourgeois Culture'}

From this perspective, ethnography is primarily used to analyse the contours of an entresoi in which social capital is nurtured and maintained. It focuses on those moments when the group mobilises and expresses a common cultural background. The observer, however, faces one methodological problem: how to identify what would be the specificity of a 'bourgeois culture'. Beatrix Le Wita describes 'bourgeois culture' as a 'déjà-là' (an 'already there') based on the need to control 'the historicity of society'. Bourgeois culture is defined as something only shaped by the needs of the bourgeoisie (Le Wita 1990, p. 10. Le Wita 1994). The bourgeoisie, according to this definition, have a 'mobile' culture and control their own cultural referents; they have the ability to adapt their culture to their daily needs, which explains its elusive and ever-changing character. The power of the bourgeoisie, from this perspective, lies in the specific nature of their culture.

To illustrate this in research, the ethnography of bourgeois traits of culture focuses on specific moments and interactions. But several elements are still regularly absent from this type of fieldwork and have yet to be elevated in a proper ethnographic object of investigation as a way to break with the lens of 'cultural isolation' through which bourgeois practices are seen. What is at stake in these moments of intense sociability between peers, these moments when the group is seen in and of itself performing the social rituals that maintain its collective self? Do the bourgeoisie only spend their time sending their children to selective schools, attending their private clubs, going from these clubs to their swimming pools, and then further to attend their selective parties?

The links between the aristocracy, or the bourgeoisie, and politics, and in particular the links with political parties, are a dimension often absent from these

\footnotetext{
${ }^{5}$ To borrow the title of a special issue on elites of the journal French Ethnology published in 1990 (Vol. 20).
} 
ethnographic accounts of 'bourgeois culture'. Recent research clearly shows, for example, the distant relationships of the upper classes to classical forms of activist work (door to door distribution of leaflets, participation in electoral events, etc.) (Agrikoliansky 2013; Geay 2019). But this distance does not mean that the great bourgeoisie do not have a link to the political field that could be further explored, including whether it is tied through informal partnerships or funding. Another dimension often absent from these ethnographies of bourgeois culture, which tend to be quite family-centred, is work or - if we consider that the term work is not suitable for the description of activities linked to capital incomes (Barthélémy 2005) the issue of the maintenance of economic capital and its reproduction. Even the most disinterested inheritor by material standards is probably concerned with what is happening to his resources. At the very least, he will have links with a series of advisors managing his assets.

To sum up, even a researcher whose primary purpose is to describe 'bourgeois culture' would do well to follow these agents in other social arenas to grasp the instances when this supposed 'bourgeois culture' confronts institutional norms, laws and interactional arenas that are not structured solely by the codes of mundanity. These moments, however, won't show the bourgeoisie demonstrating less dominant traits (one could observe, for instance, the asymmetry between the upper class and desk officers in charge of tax adjustment) (Huret 2014; Spire 2013). Rather, these moments would show elites benefiting from symbolic power, likely profiting from social interactions with other groups. These dominant agents would then be grasped in the wide panoply of social arenas in which they are immersed. It is through appearing in all these social arenas that the bourgeois agents' dispositions are acquired and transformed through primary or secondary socialisation.

If bourgeois culture evolves, it is not because the bourgeoisie has the ability to change its culture or benefits from a 'mobile culture' but more commonly because facing a series of institutional orders with their own changing rules (the evolution of multinational firms, the transformation of the education system, the changes within the political field, etc.), this social group has to constantly adjust itself to other organisational principles than those of bourgeois worldliness. Ethnography of the ruling classes, by obscuring these other social arenas, spreads the idea of a united and cohesive group at the expense of analysing the constant influence of institutional orders. This is particularly true when we consider studies on education and social reproduction. Few works, like those of Shamus Khan, consider seriously the meaning of the relative maladjustment of some well-born children responding to the changes impacting the field of ultra-selective schools (Khan 2011). We will defend here the idea that ethnography can contribute to re-embedding these dominant agents in the multiple relationships that tie them to different groups or social activities. 


\section{Power Elites Without an Observable Power?}

For opposite reasons, researchers mainly using statistics and who are part of the debate on the monistic or pluralistic character of our elites also avoid dealing with the issue of qualitative analysis of symbolic power. Defining elites through their occupation of high positions in different institutional orders, they endlessly debate over the divided or united nature of 'elites', thereby losing sight of which social groups these institutions draft their troops from.

The methodological problem here is that we can certainly assume that the occupation of high positions provides capital and chances of power. However, you cannot deduce only from occupied positions the existence of common spheres of practices, producing a common ethos. No room is given to the operation by which resources are transformed into 'symbolic power', through new and specific capital linked to a field. The simultaneous presence of individuals in certain places (in the physical sense) does not mean the production of a common principle that generates common practices or symbolic power. As Bourdieu emphasises in Outline of $a$ Theory of Practice, 'the search for correlations or factorial analysis cannot lead us to the system of rules which generates regularities, neither in the case of an economically and socially undifferentiated society, nor in a stratified society, within the same social class' (Bourdieu 2000a, b [1972], pp. 281-282) struction of a class ethos may, for example, make use of a reading of statistical regularities treated as indices, without the principle which unifies and explains these regularities being reducible to the regularities in which it manifests itself' (Bourdieu 1977, p. 85). A similar criticism could be made of interlocking directorate studies which hastily infer the existence of a community of interest from the simultaneous presence of agents on the same boards of large firms.

It is on this point that ethnography likely has its own and very specific utility. Ethnography can help with exploring what is hidden behind statistical regularities and not only by highlighting specific cultural principles typical to the bourgeoisie or aristocracy. By focusing on how the practices of the agents are confirmed, disrupted and updated in different social arenas and how they face different institutional orders, it may be possible to avoid the pitfalls of the ethnological approach of bourgeois culture (the description of a 'mobile culture') and the limits of an institutional approach (which starts by analysing institutional positions only to end up in an analysis of common psychological traits). There is not, on one side, a 'bourgeois culture' made of homes on the beachfront and, on the other side, top positions in power institutions occupied by interchangeable agents listed by biographical directories. What we need to grasp is precisely the areas of intersection between social institutions and dominant groups.

\footnotetext{
${ }^{6}$ Author's translation; this passage is not included in the English edition from 1977.
} 


\section{Beyond an Ethnography of Mundanity: How to Grasp Symbolic Power in a Relational Context?}

According to Willis (and here we should transpose this statement to the ruling classes), 'class cultures are created specifically, concretely in determinate conditions, and in particular oppositions. They arise through definite struggles over time with other groups, institutions and tendencies' (Willis 1977, p. 59). The idea of a 'bourgeois culture' shaped by confliction with other groups and institutions has merit in that it rules out the idea of a 'bourgeois culture' having in itself a capacity of adaptation that other cultures have not. Rather than drawing the contours of a bourgeois culture (or popular culture), the ethnographer should seriously consider those moments where the practical sense of agents listed in biographical directories faces evolving institutional orders.

\section{A Constant Socialisation Between Class Positions and Institutionalisation Processes}

A bourgeois socialisation probably provides resources to access positions on the boards of the larger firms, but these companies are at the same time impacted by large changes (growth of financial capitalism that requires adaptation and new strategies such as creating family holding companies). Dispositions imported into institutions in this way change and become re-combined. Ethos is not only formed inside the entresoi but also serves as a protective mimicry, and is shaped through external confrontations. Transposed to the study of the dominant classes, such a research programme implies that we should, as a first step, study how the army creates its own way of being a 'bourgeois/colonel', the Church a 'bourgeois/cardinal', the bank a 'bourgeois/leading banker, etc. Then, in a second step, we should analyse how these differentiation processes from 'bourgeois' primary socialisation renew the values and practices of these privileged groups. It would then appear that this 'bourgeois culture' does not change because of its mobile nature but because of its permanent confrontation with institutional orders which leads to the re-importation of these micro-adjustments into the entresoi. By doing so, it would be possible to circumvent the pitfalls of an ethnology of the ruling class, and finally break with the notion of 'culture', which some anthropologists for years have argued for.

By defining upper class practices as a part of a specific culture, a circular concept is produced. 'Bourgeois culture' becomes defined as an entity composed of practices ('the practice of genealogy', 'the taste for legitimate culture', etc.). If, to save the concept of bourgeois culture, we emphasise the strength of beliefs that are the principle of practices, the risk is to fall back into a form of mentalism considering 'bourgeois beliefs' as a unified system explaining practices. The notion of 'bourgeois culture' can at best be a tool for describing at first glance a more complex reality. By isolating the analysis of practices from its confrontational social 
environment, it freezes singular moments of interactions that need to be analysed as a process and therefore are continuously shaped by all the social relations in which they are embedded.

Moreover, we should resume critiques that Pierre Bourdieu puts forward in Pascalian Meditations against the 'thick description' of Geertz or anthropologic culturalism. When it comes to studying elites, we should take seriously the criticism of any anthropological practice that does not include in its theory the distance between practical logic and scientific logic. To explain the practices of dominant agents observed during fieldwork through the notion of bourgeois culture is 'imputing to its object what belongs to the way of looking at it; it projects into practice (with, for example, rational action theory) an unexamined social relation which is none other than the scholastic relation to the world. Taking various forms depending on the traditions and the domains of analysis, it puts a metadiscourse (a grammar, a typical product of the scholastic standpoint, as with Chomsky) at the origin of discourse, or a metapractice/.../at the origin of practices' (Bourdieu 2000a, b, p. 53).

A second danger with the notion of 'bourgeois culture' refers more specifically to the conventional and critical remark of Claude Grignon and Jean-Claude Passeron in Le Savant et le populaire (1989): a relationship of domination cannot be conceived of by separating the effects of this relationship on both the dominated and dominant who are symbolically associated. One cannot imagine a 'bourgeois culture', that is to say, a symbolic production that would be independent of a relationship of domination. If bourgeois culture exists, it cannot be separately analysed from the categories it produces to differentiate different social groups; bourgeois culture exists only in opposition/relationship to other groups and even provides 'names' and categories to create a distance with them.

This relative uncertainty and active dimension of social asymmetry have mainly been explored in urban sociology. The mobilisations of upper classes to maintain their territories makes particularly visible the existence of these active processes of adaptation and conflictual differentiation. We are thinking here in particular of the work of Monique Pincon-Charlot and Michel Pinçon, and also of Sylvie Tissot, that addresses urban and neighbourhood struggles (Tissot 2015). If we transpose this sociological approach to the sociology of workplaces, ethnographic practice should then lead us to explore all those moments when the maintenance of social status for the ruling classes appears as a social activity in itself.

\section{An Exploration of the Dispositional Adjustments and the Valuation of the 'Symbol of Class Status'}

Ethnography of the field of power should particularly focus on dispositional adjustments and seek to describe the system of correspondences between models of achievements provided by different institutions (the 'good boss', the 'good political leader', etc.) to link them with the already known features of aristocratic or 
bourgeois tastes. This is one of the strengths of ethnography: not only signalling the outline of a culture but also concretely showing how whole areas of social practices are articulated, how what has been learned in primary and secondary socialisation facilitates the occupation of high institutional positions and, in reverse, how playing social roles always involves adjustments.

If ethnography is used as such, spots of observation have to be chosen on the basis of the probability they offer for providing opportunities to observe the confrontation between agents belonging to the upper class, and also the specific rules of a field which filter access to positions of power. In this way, the most central places to the bourgeois way of life may not be the most interesting spots of observation. To grasp how symbolic power is exerted and related to the possession of resources recognisable by third agents, one should focus on sites of power and explore them as places where agents with an upper class background are immersed in a specific field with its own logic.

\section{An Ethnography of the Sites of Power}

In his book The mediation of power, Aeron Davis suggests that we should stop trying to study the power of powerful people, which is hard to measure, in and through the media and rather focus our attention on the sites of power that we can explore, such as, among other things, the relationship these individuals have to the media (Davis 2007). Such an approach suggests capturing dominant agents 'at work' and in their daily context (for instance, asking what the cultural practices of MEPs are or how MEPs deal with journalists, instead of focusing on how MEPs become dominating citizens through the power of the media).

\section{An Ethnography of the Habitus of Dominant Agents 'At Work'}

An ethnography that focuses on the habitus of dominant agents allows one to grasp how the capital owned by these agents is perceived as it is mobilised in the maintenance of social positions. MEPs, traders and journalists actively compete against other players. The efficiency of their resources is partially uncertain and earlier socialisation becomes partly reshaped in the social arenas investigated. Qualitative methods no longer describe a culture but a struggle in a field. We could here underline how Karen Ho addresses the issue of daily interactions (including the trivial evaluation of clothing choice) in her ethnography of Wall Street (Ho 2009). These brilliant students from the best Ivy League institutions are first drafted through the promise of a highly privileged status in a famous bank. But the adjustment to their first job position in this elite arena is not so natural. They first have to face a test based on overwork. Daily interactions in investment banks redistribute the symbolic resources of these Ivy League recruits turned managers. They are classified and 
reclassified according to their adjustment to their job position, and their career in the bank now becomes linked to their ability to conceal any distance to the very particular investment banker ethos. Gender hierarchies also fully play their role within this elitist workplace just as statutes and potential social mobility are daily defined. Here, ethnography is not used to describe the bank only as an entresoi, rather the bank comes across like a competitive field where social differences play a role in producing hierarchies between the actual practices of the new recruits.

These sites of power can be much more interesting spots of observation for sociological work than more mundane sites like private clubs. These are stable social arenas at little distance to the $1 \%$, privileged observation spots of the regular and repeated confrontation between agents belonging to different dominant social groups and institutional orders. By observing in these sites 'small' social mobility (for instance, from the lower fractions of the bourgeoisie to upper sections of the bourgeoisie), we can also more easily analyse interactional logics that structure relationships of domination and the expression of a symbolic power. Symbolic power has, of course, to do with the credit granted or not given to others. In his article on the field of the Grandes Écoles, Pierre Bourdieu gives a relational definition of symbolic capital that is useful for ethnographic fieldwork. He writes that 'the best measure of the position of an institution (or individual agent) in the distribution of symbolic capital lies undoubtedly in an index taking into account an assessment of its socially recognised claims (granted by its competitors) as well as the gap between these claims and its asserted, self-ascribed claims' (Bourdieu 1977, pp. 3-30; author's translation). Since the logic of symbolic capital responds to a logic of 'to believe and make others believe', symbolic power has to do with thirdparty certification of social resources.

\section{An Ethnography of the Differences Between Objective Properties and Given Credit}

If an ethnographer seeks to analyse symbolic capital in context, he must abandon the description of salient outlines of a bourgeois culture to pay attention - for instance - to the discussions when agents talk together about other agents and give credit to one of them because of his 'specific' potential. What are the naturalised traits that are given as a 'credit' to an agent and thus that function as efficient capital recognised and updated? The ethnographer should notice that this credit, only given to a handful of agents, allows them to do things others cannot, to access places without limits (not needing to show their ID, for example). The differences between self-perception and the perceptions of others are difficult to measure. But in some workplaces where assessment is formalised and recurring (including senior management), the ethnographer can likely benefit from material traces of these differences: by contrasting, for example, the positions to which an agent applied (available in his career records) and the positions to which he seems sufficiently qualified according to the viewpoints of his supervisors. If we consider agents with 
comparable resources, how can one agent be given a credit whereas others cannot? What are the collective practices through which objective resources produce something that others cannot afford?

Symbolic capital has something to do with the efficient but localised recognition of possessed capital. It presupposes the existence of a field, a relational structure of agents able to bring objectively measurable resources to a higher level of collective recognition. This means, for instance, that the ethnographer should pay attention to moments when collective operations of redistribution and reallocation of tasks, as well as the rewards associated with them, are played out (for instance 'how is it decided who will be in charge of this important case with related subsequent chances of social mobility?').

In a recent review of 'The Sociology of Elites', Shamus Khan suggests defining elites as agents having control over resources or having the ability to redefine their resources as valuable. We could add that in order to grasp what is symbolic power, one should pay attention to these moments when the collective definition of what constitutes a particular type of capital is described as exceeding the sum of the capital objectively possessed by agents. What is at stake when a group is led to a naturalised social verdict, a collective recognition of the full embodiment of the expectations of a field (the musician dedicated to music becoming 'a natural born musician' etc.)? An ethnography of symbolic capital does not only presuppose the isolation of the few cultural practices that will be analytically erected to the rank of distinctive practices of an elite group. Rather, it aims to understand how the observed group gives more credit to some agents, recognising - between agents with comparable possession of capital - extraordinary or rare properties and talking about them with reverence, as these 'happy few' have embodied all the expectations of the field. Using a variety of methodological tools and techniques when observing the interactions in which the revaluation and reclassification of the agents' symbolic capital take place, the ethnographer creates the conditions for writing an ethnography of symbolic power that avoids falling into the culturalist trap.

\section{References}

Agrikoliansky, E. (2013). Du côté des classes supérieures: politisation et engagements des classes supérieures dans la France contemporaine, Habilitation à diriger des recherches. Paris: Université Paris Dauphine.

Barthélémy, T. (2005). Le travail des rentiers. In P. Marcilloux (Ed.), Le travail en représentation (pp. 367-382). Paris: Editions du CTHS.

Bensa, A. (2006a). La fin de l'exotisme. Toulouse: Anacharsis.

Bensa, A. (2006b). Pierre Bourdieu and anthropology. In R. Lardinois \& M. Thapan (Eds.), Reading Pierre Bourdieu in a dual context: Essays from India and France. London/New-Delhi: Routledge.

Bourdieu, P. (1977). Outline of a theory of practice. Cambridge: Cambridge University Press.

Bourdieu, P. (2000a[1972]). Esquisse d'une théorie de la pratique. Paris: Point, Coll. Essai.

Bourdieu, P. (2000b). Pascalian meditations. Berkeley: Stanford University Press. 
Dalloz, J.-P. (2009). Sociology of elite distinction. From theoretical to comparative perspectives. Basingstoke/New York: Palgrave Macmillan.

Davidoff, L., \& Hall, C. (1987). Family fortunes: Men and women of the English middle class, 1780-1850. Chicago: University of Chicago Press.

Davis, A. (2007). The mediation of power: A critical introduction. Routledge.

de Saint Martin, M. (1993). L'espace de la noblesse. Paris: Métaillé.

Elias, N. (1983). The court society. New York: Pantheon Books.

Geay, K. (2019). Enquête sur les bourgeois. Aux marges des beaux quartiers. Paris: Fayard.

Grignon, C., \& Passeron, J.-C. (1989). Le savant et le populaire, Misérabilisme et populisme en sociologie et en littérature. Paris: Seuil.

Ho, K. Z. (2009). Liquidated. An ethnography of wall street. Durham: Duke University Press.

Huret, R. (2014). American tax resisters. Cambridge: Harvard University Press.

Khan, S. (2011). Privilege. The making of an adolescent elite at St. Paul's School. Columbia: Columbia University Press.

Le Wita, B. (1990). Comment en sortir? Ethnologie Française, 20, 5-11.

Le Wita, B. (1994). French bourgeois culture. Cambridge: Cambridge University Press.

Mills, C. W. (1956). The power elite. Oxford: Oxford University Press.

Pareto, V. (1991[1901]). The rise and fall of elites: an Application of theoretical sociology. New Brunswick: Transation Publishers.

Pinçon, M., \& Pinçon-Charlot, M. (1999). Grand fortunes: Dynasties of wealth in France. New York: Algora.

Shore, C., \& Nugent, S. (2002). Elite cultures: Anthropological perspectives. London/New York: Routledge.

Sombart, W., Esptein, M. (1967[1913]). The quintessence of capitalism: a study of the history and psychology of the modern business man. New York: H. Fertig.

Spire, A. (2013). Faibles et puissants face à l'impôt. Paris: Raisons d'agir.

Tissot, S. (2015). Good neighbors. Gentrifying diversity in Boston's south end. London/New York: Verso Books.

Veblen, T. (1934). The theory of the leisure class. New York: Random House.

Willis, P. (2009 [1977]). Learning to Labour. London: Ashgate.

Open Access This chapter is licensed under the terms of the Creative Commons Attribution 4.0 International License (http://creativecommons.org/licenses/by/4.0/), which permits use, sharing, adaptation, distribution and reproduction in any medium or format, as long as you give appropriate credit to the original author(s) and the source, provide a link to the Creative Commons license and indicate if changes were made.

The images or other third party material in this chapter are included in the chapter's Creative Commons license, unless indicated otherwise in a credit line to the material. If material is not included in the chapter's Creative Commons license and your intended use is not permitted by statutory regulation or exceeds the permitted use, you will need to obtain permission directly from the copyright holder.

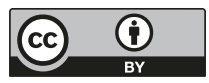

